OPEN ACCESS

Edited by:

Lauren Withycombe Keeler, Arizona State University, United States

Reviewed by:

Scott Cummings,

UCLA School of Law, United States Voltaire Alvarado Peterson, University of Concepcion, Chile

*Correspondence:

David Amacher david.amacher@posteo.de Markus Kip

markus.kip@gsz.hu-berlin.de Daniel Opazo

daniel.opazo@uchilefau.cl

Specialty section

This article was submitted to Governance and Cities,

a section of the journal

Frontiers in Sustainable Cities

Received: 18 August 2021 Accepted: 27 December 2021

Published: 31 January 2022

Citation:

Amacher D, Kip M and Opazo D (2022) Territorialized Commons and

Social Movements: Legal Appropriations of Collective Spaces in

Berlin and Santiago de Chile. Front. Sustain. Cities 3:760548. doi: 10.3389/frsc.2021.760548

\section{Territorialized Commons and Social Movements: Legal Appropriations of Collective Spaces in Berlin and Santiago de Chile}

\author{
David Amacher ${ }^{1 *}$, Markus Kip ${ }^{1 *}$ and Daniel Opazo ${ }^{2 *}$ \\ ${ }^{1}$ Georg-Simmel Center for Metropolitan Studies, Humboldt-Universität zu Berlin, Berlin, Germany, ${ }^{2}$ Department of \\ Architecture, University of Chile, Santiago de Chile, Chile
}

This article aims to explore the relationship between territorialized commons and movements and how the use of legal strategies of appropriation mediates this relationship. We study two recent commoning practices for collective space in Berlin and Santiago de Chile that have appropriated publicly owned land for their initiative, engaging with legal institutions to meet the ends of the movement. This type of relationship to movements has not been given serious consideration in the commons literature and we ask how these commoning initiatives make the appropriated land a common resource for the movement and resist privatization. Based on secondary sources and interviews with activists, we conclude that both initiatives in Berlin and Santiago de Chile have drawn on legal frameworks for transformative purposes while also politicizing the question of public land as an asset for civic and commoning use. However, said frameworks do not replace activist engagement and self-organization as the main element behind commoning processes.

\section{Keywords: commons, social movements, collective space, Berlin, Santiago de Chile, legal strategies}

\section{INTRODUCTION}

Scholarship on the commons following the line of Ostrom (1990) has shown how commons arrangements worldwide have sustained themselves over long periods without falling prey to freeriding practices. For the most part, scholars from the common-pool resource approach with similar observations (Quintana and Campbell, 2019) relate to situations that are in comparatively stable political-economic conditions and that allow for the institutionalization of commoning efforts in reliable ways. Other scholars have been concerned with commoning expansion as a real and forceful alternative social dynamic that enters into historical conflict with neoliberal forms of subjectivation and social organization (Habermann, 2008; Hardt and Negri, 2009; De Angelis, 2017); with capitalist forms of production and allocation of goods (Bauwens, 2009; Bollier and Helfrich, 2019). Explicit consideration of the emergence of new territorialized commoning experiments in relation to movement dynamics is rarely made (but see Blanco et al., 2019, p. 4; Della Porta et al., 2017).

In this paper, we seek to connect territorialized commons and movements and explore how the use of legal strategies of appropriation mediates this relationship. In particular, focusing on the intersections of urban housing movements and commoning experiments for collective social spaces, we seek to understand better how the legal appropriation of territories for commoning 
is integrated (or not) as a resource for broader movement concerns. We considering recent commoning practices for collective space in Berlin and Santiago de Chile that have appropriated publicly-owned land for their initiative. We ask how these commoning actors relate to property law and state policies. While the case studies don't claim to be representative, they are widely referenced and discussed in their respective national context in terms of their innovative approaches toward legal strategies of appropriation. In this paper, we seek to better understand the reasons for social movement actors to draw on legal instruments for appropriating territories and the implications for how these territorial commons relate to the larger commoning movement. Both cases exemplify how legal options are taken advantage of to stop the commodification of land and instead of making it available to the needs of workingclass neighborhoods. In both instances, these legal strategies also imply mechanisms to safeguard against the risk of commoners privatizing certain pieces and making a profit (as in the case of cooperatives), and they also help enshrine certain commitments to the movement and the surrounding neighborhoods. Another key movement contribution by the initiatives relates to their sharing of experiences, the politicization of using (public) land for civic purposes, and their political engagements with policies to facilitate similar approaches elsewhere.

\section{SPEAKING OF COMMONS... METHODOLOGICAL REFLECTIONS}

A look at international journals of scholarship on urban or social movement studies demonstrates that research on commons, and urban commons in particular, primarily refers to experiences in the Global North or is written by researchers working at an academic institution in the Global North. Clearly, this difference is not explained by a lack of urban commons experiences in the Global South or commoning movements (see e.g., Kuttler and Jain, 2015; Opazo, 2015). This discrepancy raises the importance that research on the Global South and by scholars working in this part of the world be given greater attention. Comparative research between Global North and South that seeks to open up to new insights and possible theoretical revision, cannot treat case studies in the Global South as mere examples proving a point of already existing theoretical frameworks (Connell, 2007). The challenge but also the promise of a comparative perspective is that it puts conceptual frameworks, questions and findings that were relevant in the Global North into perspective (Robinson, 2016).

However, when engaging in our transnational conversation, we must name at least the most influential structural and institutionalized mechanisms in the globalized political economy of research and higher education that underlie this research collaboration between Berlin and Santiago de Chile. From this particular point of critique, we recognize the larger coloniality of power (Quijano and Ennis, 2000) in which our positions as researchers are inscribed.

Various academic institutions or the researchers themselves in the Global South do not count on the resources to afford article processing charges (APC). In several academic institutions in the Global South, there are policies in place that advise against the publication in journals or other projects that charge fees on authors. By contrast, in the European Union, Open Access research policies are put in place that encourage the development toward open-access APC journals (Chiodelli, 2021). Even when APC journals offer the option to waive fees in some cases after the manuscript has been accepted, we must consider the APC principle as a significant disincentive, since the preparation of an article carries the additional risk that fees may not be waived.

Through a collaboration between researchers in the Global North and South, it is possible to solve the costs by providing funding from Northern academic institutions to cover the APC, but it places the relationship amongst researchers on an unequal plane and requires careful consideration. This collaboration goes back to Daniel and Markus becoming acquainted in the context of the Urban Commons conference in Berlin in 2013 and subsequent collaborative endeavors (see Kip et al., 2015; Opazo, 2015).

Assuming that there are no privileged vantage points, no original, no authentic case study, we took advantage of our transcontinental relationship to jump into the global rhizome from our respective vantage points (Deleuze, 1995; Robinson, 2016)-Santiago and Berlin. Robinson (2015), in particular, recommends a comparative approach to think about urban phenomena "through the elsewhere" and thereby generating or revising concepts. Reflecting on the relationship between social movements and (territorialized) commons across the geographical distance of Santiago to Berlin forces us to be more explicit about their respective contexts and assumptions that our theories at hand make. Rather than confining our comparison to pre-existing concepts such as "globalizing" or "global cities" with a conceptually narrowed perspective distinctive to Northern or Western institutional contexts (Robinson, 2006), we began by sharing views on urban issues that mattered to us in our respective contexts, that struck us as innovative and with potential for further developments. This process resulted in our decision for a comparison of legal appropriations for commoning after having exchanged ideas in teleconferences about urban commons and movements in each city. Having identified new experiments with the law as a field of innovation for commons movements, we wanted to find out more how these engagements with the law to appropriate territories are negotiated within movements in Berlin and Santiago. Two case studies were decided on, not as representative for each context, but as promising entry points to examine movement negotiations in each case and to foster comparison across these cases. Hence, we embarked on research in our respective cases, building on our local understandings of the context, research site observations and interviews with experts in each context. The Berlin research also drew on data gathered by the EU-funded Open Heritage research project that Markus and David worked for (see e.g., Polyak et al., 2019). After having presented to each other our findings of each case study, we tried to take seriously the assumption we cannot fully understand cases, particularly activist practices, in any national or even continental context alone (see Wood, 2012). 


\section{GIVING BACK TO THE MOVEMENT: COMMONS AND RESISTANCE TO NEOLIBERALIZATION}

Even when over the past centuries, many commons have been enclosed through processes of primary accumulation (Wood, 2017), commons never completely vanished and commoning has been practiced parallel to capitalist modes of social organization. Linebaugh (2008) historicizes the spatiotemporal relations between commons and enclosure and posits that waves of privatization of public resources and land through neoliberalization (see also "roll-back" and "roll-out" neoliberalism, Peck and Tickell, 2002) relate to what Marx conceived of primary accumulation. However, these practices of enclosure are confronted with endeavors of defending, maintaining and reclaiming commons (Federici, 2010). As Caffentzis (2016) points out: "[i]n the context of widespread struggles to defend against neoliberal assault, radical interest in 'the commons' revived." Many scholars address efforts to establish commoning spaces in urban environments under the term "urban commons" (Borch and Kornberger, 2015; Kip et al., $2015)$ as a reaction to so-called uneven "austerity urbanism" (Blanco et al., 2019) or "new waves of privatization" (Linebaugh, 2008). Blanco et al. (2019) observe three main reactions to austerity urbanism: (1) episodes of social protest (2) spaces of social autonomy following the logic of the commons, and (3) new political subjects and organizational forms. We observe all three elements in both case studies, albeit in different forms and intensities.

Urban commons research has often focused on "spaces of social autonomy," e.g., urban gardening (Sardeshpande et al., 2021), Community Land Trusts (Bunce, 2016), Mietshäuser Syndikat (e.g., Barthel, 2020). However, a strict division between protest movements, spaces of social autonomy and new political and electoral subjects would be artificial and doesn't do justice to their interrelated and codependent linkages that are peculiar in each geographic context. Also, we need to address the question of how these many commons "can form a cohesive whole and provide a foundation for a new mode of production" (Federici, 2010, p. 286). Research on the interaction of these spheres has mostly focused on strategic concerns of activists on how to cooperate with private and state actors (create alliances) to secure or establish a commons in a neoliberalized regime (Bunce, 2016; Aernouts and Ryckewaert, 2018). These "timely partnerships" (Panelli and Larner, 2010) and governance-focused studies have shown that "community activists and state actors and processes continuously reshape each other to create new spaces of access to and for the mobilization of resources" (Bunce, 2016, p. 140).

We need to emphasize that the commoning projects in both cases are embedded and sustained within broader movement dynamics of austerity protests and realizing experimental forms of social life. Thus, the cases should not be mistaken as the quintessential expressions of the movements. Still, De Angelis (2017, p. 361) emphasizes "territorial rootedness" as an important feature of commons movements. Thinking about the relationship between social movements and commons, de Angelis writes "social movements can only contribute to the making of alternatives; they themselves are not the alternative" and further: "social movements need to organize their own practices of commoning necessary for resources and the reproduction of their members-food, security, logistics, tents, fundraising, and so on" (De Angelis, 2017, p. 368). Social movements thus can embed commons, but the reproduction of commons and their communities is usually dependent on institutionalizations that are the result of struggles with capital and state actors (De Angelis, 2017, p. 369-70). If this interaction between social movements and commons is repeated and becomes sustained, a commons movement emerges, creating an ecology of commons for movement members (De Angelis, 2017, p. 385).

In this article, we want to shed a light on how these appropriated territories may become a strategic resource and a stake of struggle for movement activities at large without ignoring the fact that this is not the only political dimension of commoning. Many authors have emphasized how these spaces of commoning may transform everyday life and modes of social reproduction securing a better life in the here and now (Van de Sande, 2017; Mensink, 2020). Therefore, we do not want to reproduce the "separation between the personal and the political, and between political activism and the reproduction of everyday life" (Federici, 2010, p. 290). Our goal is to bring into dialogue how these commoning spaces link and interact with broader movement actors to see how they can be brought together.

From a social movement perspective, territorial commons can be considered a social infrastructure for movements around certain goals or niches in which alternative modes of social (re-)production can be lived. In terms of their material aspects, these collective spaces include a territory and physical structures that allow for physical encounter, self-organization and for addressing vital movement needs such as a place for provisioning food, discussing, resting, celebrating, and so on. Pruijt (2014) observes how squatter's spaces in Amsterdam can provide an infrastructure for a bigger movement. The social functions for movements that these spaces can entail are manifold: From bars and clubs as spaces of encounter, as well as sources of funding through benefit parties ("Soli-Parties"). Another strategy was the institutionalization of consultation hours to share and transfer knowledge with people who want to squat themselves. For Germany, Wendt (2018) shows how a network of collectively managed houses in Leipzig (Leipziger Kollektivhäuser organized in the umbrella association "Haus- und WagenRat e.V.") tries to open up the ground floors of the houses to the public. They also provide a support infrastructure for the local scene of housing projects e.g., through consultation. Similarly, Vey (2016, p. 67) in her analysis of a network of decommodified houses called Mietshäuser Syndikat, demonstrates the houses' "double strategy of direct action and engagement in a political arena on the communal and federal level." While the members seek to pursue a collective (and decommodified) life within their house communities, they also intervene in the meso and macro level of politics through campaigning. 
Moreover, appropriated places can become important symbolic or ideational resources for collective identification among movement actors, as we have seen in the recent past famously with the Gezi Park, Tahrir Square, Zuccotti Square Park, Maidan Square (Ersoy, 2015; Stepnisky, 2020), but also with lesser-known examples of public spaces such as Plaza Italia, renamed as Plaza Dignidad in Santiago during the 2019 "social uprising," or the Parque Indoamericano in Buenos Aires during 2010 (Hölzl, 2017); occupied hotels as the "sanctuary hotel" in Minneapolis in the context of the Blacklivesmatters protests in 2020 (Chua, 2020) or the Hotel City Plaza, occupied by refugees and supporters in Athens (Agustín and Jørgensen, 2019). Thus, from a perspective of the resource mobilization paradigm (McCarthy and Zald, 1977; Jenkins, 1983; Edwards and Kane, 2016), these territorial commons can be considered a resourcea movement infrastructure, a staging ground, a symbol-for movement activities and potential movement expansion.

But territorial commons are not just resources (that movements presuppose), they are also the target and achievement of movement actions. Scholars operating with the political opportunity structures paradigm (Piven and Cloward, 1977; Kitschelt, 1986; Meyer and Staggenborg, 1996) place attention to the enabling or disabling political conditions for movements to develop. A key insight is that conflicts within the political regime can facilitate movement dynamics by allowing for new alliances that open up new possibilities for movements to achieve particular goals - including the appropriation of territories.

Holm and Kuhn (2011) point out how squatting in West Berlin in the early 1980s took advantage of a political opportunity opened up by conflicts within the municipal regime on the brink of a transformation from a Fordist to a post-Fordist mode of governance (Mayer, 1994). However, once the postFordist mode of governance became hegemonic, conflicts arose within the squatting movement, between the negotiators and non-negotiators about the political strategy of the squatting movement (Holm and Kuhn, 2011, p. 651). This conflict was triggered also by governmental actors who emphasized the positive contribution of the "good squatters" for a cosmopolitan and colorful branding of the city while criminalizing the "bad" ones (see also Schmidt, 1998; Van de Geyn and Draaisma, 2009). The negotiating "good squatters" were subsequently accused by the autonomist squatting fraction for selling out and withdrawing from the movement by reducing their activities to preserve their own squats through legalization (Schwarzmeier, 2001).

In the case of Santiago, there are experiences of governmental repression of commons via the argument of transforming the territories into public spaces, in a city with great deficits of such spaces (Opazo, 2015). Yet, social movements have also seized political conflict and institutional weaknesses to increase pressure on the state to yield to the demands for the purchase of land for housing (González, 2021). There is also a political continuity of the pobladores movement in certain areas of the city where long-time struggles for the right to housing continue to identify and inspire new generations seeking territorial appropriations (Pérez, 2017). This growing awareness for commoning solutions can also be found in other experiences throughout Latin America, such as the self-managed development of sanitation and other urban services in México City (Rodríguez, 2017) or the long-term struggle of several Brazilian movements for urban reform and the right to the city (Friendly, 2017).

\section{Legal Engagements and Depoliticization}

Beyond territorial commons as a resource or a stake of social movements, a broad range of literature has addressed the trend toward depoliticization within commons. Reasons for such trends include changes of generations (Hettlage, 1987) or fluctuations among commoners through moving in/moving out bringing in new ones who are not acquainted with the process of (re-)appropriation and the involved political struggle (Huron, 2015; DeFilippis et al., 2019). DeFilippis et al. (2019) argue that living in what we may call commons does not automatically lead to a transformative subjectivity.

Emerging debates have also addressed the role of law and legal engagements in urban movement dynamics (McCann, 1994; Lehoucq and Taylor, 2020; Cummings, 2021). Fundamental critiques have addressed the relationship of movement lawyers toward other activists as well as the efficacy of legal engagements, raising their demobilizing effects for social movements (Rosenberg, 1991). While most of these accounts consider cases with the goal of policy changes or policy implementations, our case at hand looks at legal engagements with the aim of realizing ownership for a collective. Bearing in mind the argument by DeFilippis et al. (2019, p. 813) that "[p]olitically transformative content does not automatically inhere in the form of ownership" (DeFilippis et al., p. 813), there is no reason to romanticize the idea of legal ownership models. Ultimately, as Linebaugh (2008) and many others have highlighted: Commons is not about a resource but about the process of commoning. Therefore, legal appropriations of territory may just be a tool to promote commoning, yet without being a sufficient condition for it.

Drawing on property law as a tool, however, raises critical questions. Since legalist strategies require a certain kind of expertise, critics have pointed out that they can be connected to pursuing political agendas that are cloaked behind technical language (Kusiak, 2019). Expertise is often bound to codified knowledge from professional training, higher education, etc. (Pistor, 2019). Access to these forms of knowledge and resources is mediated through structures of oppression (e.g., classism, sexism, racism, colonialism, ableism, etc.). In this sense, we must ask how these prerequisites and systemic inequalities structure legal appropriations in specific case studies and its connection to commoning movements (esp. as the idea of legal hacking cannot be looked at without its historical basis of propertization and its implementation through extrajudicial and later judicial force). At the other end of the spectrum, legality is strategically embraced as a form of achieving credibility and legitimacy toward the public (e.g., Kusiak, 2021) as well as a tool to promote long-term stability and security within the commoning initiative (framed as "legal hacking" in the context of Mietshäuser Syndikat, see Barthel, 2020, see also case study on ExRotaprint). Moreover, the question remains what kind of legal property formats are available and chosen by the commoners-and with what kind 
of legal ramifications for the commoners and implications for movement dynamics.

\section{CASE STUDY: EXROTAPRINT, BERLIN}

One of these commoning spaces that is prominent for making use of legal appropriations in Berlin is ExRotaprint. Remarkably, ExRotaprint is a territorial appropriation that is the result of both social struggles and negotiations with the municipal state. ExRotaprint is a space that was founded in 2007 by tenants of the former Rotaprint industrial complex located in Wedding, a traditional working-class district in central Berlin. The tenants set up a legal structure comprising a heritable building right and non-profit status together with two foundations to buy the $10,000 \mathrm{~m} 2$ complex. Resisting displacement through collective organizing and protecting their space for small entrepreneurial and artistic activities against further commodification, they have also related themselves as part of a wider urban movement for affordable spaces.

The founding of ExRotaprint in 2007 marks an important innovation that influenced territorial commoning projects in Berlin, including the more recent efforts around the establishment of a foundation for setting up CLTs in Berlin ("Stadtbodenstiftung;" https://www.stadtbodenstiftung.de) and the adaptive reuse of a former school building as a community center ("PS Wedding;" https://pswedding.de), as the urban activist Sabine Horlitz ${ }^{1}$, who is involved in both projects, claimed in an interview. ExRotaprint marks an innovation at a turning point in the history of Berlin, at a moment when gentrification became increasingly visible and publicly discussed as a threat, and when the privatization policies of the municipal government became increasingly contested by urban activists. In particular, ExRotaprint pioneered a new wave of activist experiments with the legal instrument of the heritable building lease as a strategy to appropriate land and real estate for collective purposes with a long-term perspective (99 years). The heritable building lease allowed for a provision against speculative development on the site and against its sale for profit.

To understand the historical context of territorial appropriations for commoning at the time of ExRotaprint's foundation, two aspects are to be noted. First, the squatters' movement has experienced a significant decline since the early 1990s, thus a few years after German reunification in which squatters had taken advantage of abandoned buildings and a political vacuum in certain areas of the former East Berlin. After this short heyday, however, the municipal administration has been cracking down on several of the remaining squatting projects and since the 2000s, almost no new squats could be taken over for an extended period (except for the NewYorck in Berlin-Kreuzberg which was legalized, and the GerhartHauptmann-Schule which was evicted after 5 years). Second, with rising land and real estate prices in Berlin since the early 2000s, collective housing projects were faced with the ghost of profit-making. As Daniela Brahms ${ }^{2}$, one of the co-founders of

\footnotetext{
${ }^{1}$ Interview with Sabine Horlitz, May 25, 2021.

${ }^{2}$ Interview with Daniela Brahm, July 7, 2020.
}

ExRotaprint explained to us in an interview, early activists of ExRotaprint were concerned about how collective spaces and collective housing projects had been falling apart in the 1990s and early 2000s. In several instances, collective projects didn't survive the conflicts between members around realizing the increase in land value by selling off the collective space.

After Rotaprint, the manufacturer of offset litho printing presses went bankrupt in 1989, Rotaprint property was expropriated and seized by Berlin's district of Wedding. As public property, spaces within the industrial complex were rented out to artists, manufacturers and other users, mostly from the neighborhood, for short term uses during the 1990s and early 2000s. However, after being transferred from the Wedding district administration to the assets of Liegenschaftsfonds $\mathrm{GmbH}$ (Real Estate Fund), a trustee of the State of Berlin, in 2002, the real estate was offered up for sale at international property fairs seeking the highest possible price. The early story of ExRotaprint is a good example of the contested politics of "austerity urbanism" in Berlin. Since the 1990s, privatization became a panacea for financing municipal budgets. With Berlin's banking scandal in the early 2000s that multiplied the municipal indebtedness (Bernt et al., 2013), selling off housing, facilities, industrial spaces and unbuilt land became a priority to balance the municipal budget "as a conveniently quick means of reducing deficits and downsizing government within an urban politics framed by crisis" (Beveridge and Naumann, 2013, p. 190). For this reason, the Liegenschaftsfonds was created in 2001 to orchestrate this privatization process for public real estate. This restructuring of the city's real estate policy and management marks a "fundamental shift" in which public real estate became a "capitalizable asset resource" (Silomon-Pflug, 2018b, p. 60f., our translation).

\section{The ExRotaprint Initiative}

Around 2004, as some of the artists and small businesses within the compound started noticing the neighborhood's transformation and suspected a possible commodification of the industrial space, they started organizing as tenants (see Figure 1). The artists Daniela Brahm and Les Schliesser developed a concept for the complex and approached other tenants with the idea of making the ExRotaprint project together, developing a concept for the area from the perspective of the tenants. In 2005 they founded the tenants' association called ExRotaprint e.V. The association allowed the tenants to enter into negotiations with the municipal owner as a "business partner" to buy the property.

The Real Estate Fund's strategy was to sell properties as "packages" for the highest bid (Uffer, 2013, p. 157) giving a significant advantage to large scale investors compared to tenants and cooperatives with little capital. At the same time, this oligopolistic situation allowed large scale investors to negotiate discounts. Throughout this process, (Dohnke, 2013, p. 262) argues that "urban politics and policy-making centered on social equity has increasingly retreated to the background" (see also Silomon-Pflug, 2018a). Only after a portfolio deal with an Icelandic investor failed due to pressure exerted by the tenant association on politicians involved in the deal, ExRotaprint was able to resume the negotiations. The senate of Berlin 


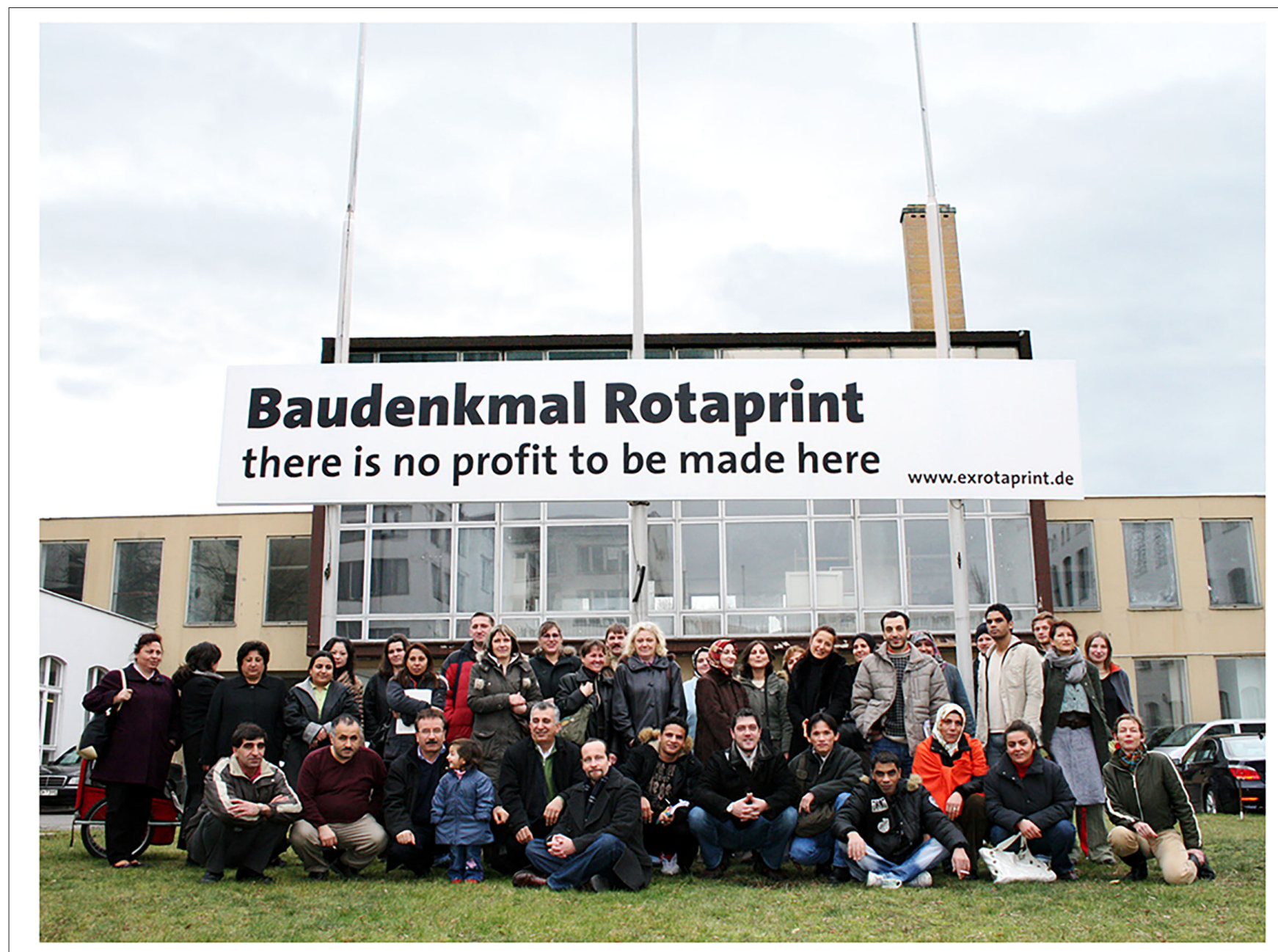

FIGURE 1 | ExRotaprint tenants in 2004. (c) Michael Kuchinke-Hofer/ExRotaprint gGmbH.

decided to release the property from the portfolio deal and the tenant association could secure the premises. While the Liegenschaftsfonds originally calculated a price of 2.4 million euros to the tenant association, the price in the supposed portfolio deal for the large-scale investor was just 600,000 euros. Once this discount bargaining news broke public, the association of ExRotaprint was able to seize the opportunity and capitalized on their social capital: Local journalists covered the matter in favor of the tenants' association making it politically impossible for the municipality to increase the price for the compound again. Moreover, the tenant association found two foundations willing to be part of the project and to back the association with financial power and expertise around developing the site. In the beginning, none of the artists or small businesses of the ExRotaprint association had counted with formal knowledge around financial and development matters, and this expertise was vital for things to get started. On September 3rd 2007 the contracts were sealed and the foundations bought the land ${ }^{3}$.

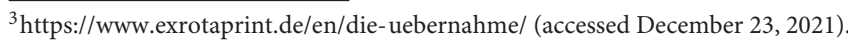

Already when entering into negotiations with the municipality, the tenant association-or at least some of their members-were well aware of the significant threat for the project to fall apart in the future as individual members might seek to realize the investment return when the real estate price of the land increases. To safeguard the purchase against speculation and individual profit-interests the tenants decided to decommodify the project through a legal construction: a heritage building right (Erbbaurecht).

Established in the Weimar republic in 1919 in order to face the post-war housing shortage and provide low-income citizens with access to land (cf. Initiative StadtNeuDenken Stiftung trias, 2017)this legal instrument allows for splitting the ownership of the land from the ownership of buildings (see Figure 2) ${ }^{4}$. The association sealed a contract with the German foundation trias

\footnotetext{
${ }^{4}$ The functioning of the heritable building right in general as well as between the foundations and ExRotaprint gGmbH is described more detailed on the website of ExRotaprint: https://www.exrotaprint.de/en/erbbaurecht/ (accessed December 23, 2021). For more recent debates regarding the use of heritable building rights in Berlin see also Initiative StadtNeuDenken Stiftung trias, 2017.
} 


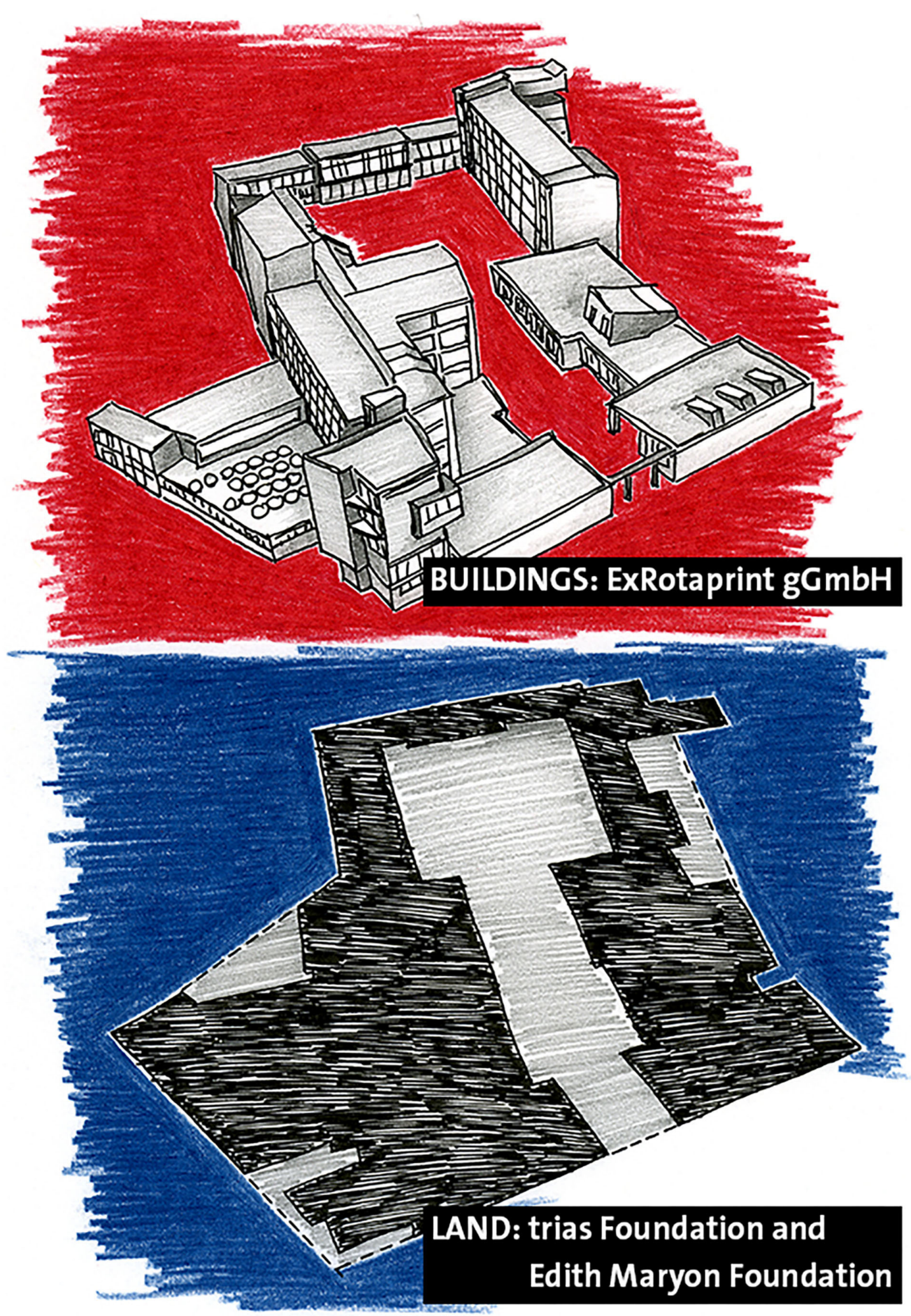

FIGURE 2 | Heritable building right at ExRotaprint $\odot$ Daniela Brahm/ExRotaprint gGmbH 
and the Swiss foundation Edith Maryon whose core task is to prevent speculation with land. Both have the ambition to secure social and ecological uses and at the same time gradually freeing the land from debt. Thus, at ExRotaprint the foundations now own the land, while the buildings on the land are owned by the ExRotaprint gGmbH, a charitable company with limited liability. This is the legal form that the tenants' association decided to establish for the take-over of the site. It is formalized in a so-called heritable building right contract (Erbbaurechtsvertrag) including an annual interest or lease fee (Erbbauzins), an agreed contract term and possible restrictions regarding the use of the land and the buildings. The ExRotaprint gGmbH was created in July 2007 and each tenant could decide if they wanted to join the $\mathrm{gGmbH}$ as well. Even tenants who chose not to be involved in the $\mathrm{gGmbH}$ could be represented through the association's membership in the company. This legal charity of the gGmbH can make a profit, which, however, must be redirected toward the company objectives that are supposed to benefit the common good. ExRotaprint occupies a position equal to ownership in regards to rights and obligations related to property management. However, the split ownership ensures that none of the owners can sell the site or the complex for profit. The contract has a duration of 99 years ensuring a long-term decommodification. While the heritable building right goes back to German law codified in 1919, it was largely unknown as a promising tool for alternative and non-profit real estate. ExRotaprint thus was a pioneer in the German context to experiment with it. As Les Schliesser claimed, "it was important for us to show that a new and different way to deal with property is possible and to make sure that the people who make up the district can continue to use the space" (quoted in Polyak et al., 2019, p. 12).

Moreover, the heritage building rights contract offers the opportunity to restrict the site to certain uses to which the ExRotaprint $\mathrm{gGmbH}$ is bound to fulfill. In this document, the concept of the tenants' association was fixed for the next 99 years, a time frame that is commonly used in heritable building leases. Daniela Brahms explains that the preamble of the company stipulates that "we rent out to work (small businesses, authors), art and community in equal parts, it's in our heritable building right, so also future generations have to fulfill it. The contracts build the framework for the future. We can do anything within this framework, and there are so many possibilities, but we are non-profit" (Polyak et al., 2019, p. 15). Thus, within this framework, ExRotaprint can decide on the process and financing of renovation or who should be able to rent spaces on the compound.

One of the central successes of ExRotaprint is to provide affordable working spaces. With 3-5.4 euros per square meter, the rent prices are remarkably low at ExRotaprint, compared to commercial rents elsewhere in Berlin that have been increasing substantially. Real estate prices have increased more than 10fold in the area since 2007. The German commercial tenancy law is less protective of tenants compared to tenancy law for housing, thus allowing for precarious conditions through shortterm contracts or graduated rental agreements. The tenants of ExRotaprint benefit largely from the low purchasing price in 2007 and the resulting low ground rents that they have to pay to the foundations.
From its foundation, ExRotaprint was strongly committed and engaged with the surrounding neighborhood and the Wedding district. ExRotaprint's rental policy was designed to invite and work with local communities, as well as to provide spaces, services and workplaces for residents. At the current moment, ExRotaprint hosts institutions that offer language classes for migrants, education for youth who dropped out of school and support services for the longterm unemployed. Moreover, the small businesses renters at ExRotaprint are expected to create jobs and benefit the district. Through the canteen and events, both open to the public, ExRotaprint has been communicating with residents in the district and Berlin more generally however, these offers are more geared toward professionals than working-class residents in the area. Considering ExRotaprint's relationship to the urban surrounding, Daniela Brahm exclaims: "We don't want to be a happy island of the creative class, we want to make something that makes sense here. If you have space you should do something for the people that directly shape the area. We want people to work here, we don't want representation, we want production here" (quoted in Polyak et al., 2019, p. 13).

One of the broader legacies of ExRotaprint in the political history of Berlin is its role in shifting the municipal government's approach away from privatizing land. Vollmer and Kadi (2018, p. 254) observe that the municipality is not proceeding to privatize public land. However, there is little public land left as most of it was privatized until the late 2000s. At Runder Tisch Liegenschaftspolitik, a municipal roundtable with politicians, civil society actors and public administrators, actors such as Daniela Brahms from ExRotaPrint and many others managed to reframe discourses around public land regarding civic engagement, transparency and tender processes. More recently, some new aspects have become part of the policy discussion such as a law to save public land ("Bodensicherungsgesetz") or the remunicipalization of land.

\section{CASE STUDY: CONJUNTO MAESTRANZA, UKAMAU, SANTIAGO}

The second case relates to a recent example of the struggles for the right to housing in Chile, where articulation between the local organization and political action beyond the neighborhood level has been a key issue.

Unlike the cases of European countries where housing provision schemes are based on tenancy, or the successful experience of housing cooperatives in Uruguay since the related law was passed in 1968 (Nahoum, 2010; Solanas, 2017), the focus of both social movements and the state structure in charge of the production of housing in Chile has historically been put on fostering housing on the basis of private property. National policies since the 1950s and up until 1970 produced on the one hand several fine architectural and urban design examples of housing complexes throughout the country; however, on the other hand, these policies only included middle classes and workers with contracts and saving capacity, leaving the urban poor with no other choice than occupying State and privateowned land to build their houses themselves (Imilan, 2016). 
Beginning with the founding of the La Victoria neighborhood in 1957, the pobladores movement arose as a new social actor, with a strong class character but also defined by their way of inhabiting the city rather than their linkage to a role as industrial proletariat. A significant part of this group were informal workers and rural migrants. Their struggle, however, was always linked to the state policies in terms of putting pressure on state agencies to either speed up processes, respond to demand or give land directly to the people to self-build. Contrary to the Berlin case, the legal framework did not allow them (nor does now) the separation between ownership of the land and ownership of the building unit (Ruiz-Tagle et al., 2021). The pobladores' model of self-help, however, was rejected during the Unidad Popular government (1970-1973), as auto-construction was considered to imply self-exploitation of workers.

The housing model of the developmental state (1925-1973) was rapidly dismantled by the civilian-military dictatorship after 1973. The military government and the "Chicago Boys" in charge of the economy "encouraged the massification of social housing in individual property, based on the ABC model (Spanish acronym for savings, bonuses and credit)" (RuizTagle et al., 2021, p. 146). According to these authors, the dictatorship model of space and housing production "achieved several objectives in the context of authoritarian neoliberal reforms: it reduced informality to a minimum (at least until the end of the nineties), expanded ownership levels to almost $70 \%$, and enabled the creation of large-scale real estate and banking businesses."

The exchange cycle between State policy and regulations, large real estate companies and the banking industry relied on low-quality urban development, poor access to services, jobs and public spaces and conditions of exclusion, both social and spatial. Already in the first decade of this century, the model was harshly criticized (Rodríguez and Sugranyes, 2004) and pobladores organizations began taking a different stance through it, reclaiming the strategic approach of their foremothers in making use of the state apparatus and even by forming small enterprises to take on roles previously outsourced to private entities (Ruiz-Tagle et al., 2021).

Drawing on a wide literature about the development of the pobladores movement in Chile during the twenty-first century, Del Romero (2018) signals the center-left government of Michelle Bachelet (2006-2010) as the context for three major changes and innovations in terms of discourse and practices within the movement: first, the inclusion of the Lefebvrian concept of the right to the city in their claims, although adapted as "good living" (linked to the idea of "sumak kawsay," a motto of several Latin American left movements inspired by Bolivian and Ecuadorian experiences) or "dignified life" (Pérez, 2017); second, the change of strategy and identity building, from mere protest to empowerment as autonomous management agents for their own housing projects; and finally, attempts at political institutionalization by participating in local and national elections as formal parties.

The articulation of these changes probably explains to a great extent the re-emergence of the pobladores movement, with the transition from a vague social subject to structured, even federated organizations as a salient feature. This re-emergence has been recently theorized by several scholars (Cortés, 2014; Angelcos and Pérez, 2017), noticing the somewhat abrupt changes regarding the development of urban and housing policies and economy during the previous decades.

The empowerment process of the pobladores mentioned above has implied not only an expansion of their roles but also of their claims, "including a concern for the characteristics of housing, the associated indebtedness, its location and the environment, all of which has been called the struggle for decent housing or the right to the city" (Herrera, 2018). Pobladores' organizations have also projected their struggle to the political system and public policy realms, devising programs and proposals regarding laws, regulations, construction administration processes, participatory criteria, housing financial policies, and even novel features for the Chilean context such as land banks (Paulsen et al., 2019).

Two prominent organizations within this new rationale of public contestation and orientation toward self-management are the Movimiento de Pobladores en Lucha (MPL) and Ukamau. MPL, based in the municipality of Peñalolén in eastern Santiago, has gained notoriety during the last decade for their initiative of creating a "popular building company" and attempting to seize the housing system's production structure to foster their vision of a collective actor ("sujeto popular") which is not an idle recipient of public policies, but instead an active agent of urban and social change.

The Ukamau movement was born in 1987, in the so-called Población Santiago in the municipality of Estación Central (a traditional working-class neighborhood), in a community and cultural space acquired with money from a Swedish NGO. Originally, Casa Ukamau housed political formative spaces and workshops for children and women. During the 90s Ukamau continued working with children and also doing educational work (completion of studies, university admission training), with many activities but with low participation, until the younger generation from the neighborhood who had been educated in Casa Ukamau began to participate in the student movement and the popular education networks, during the second half of that decade. The young people who participated in Ukamau were also linked to the culture of resistance and memory of radical subversion around Villa Francia, a neighboring area. This stage of the movement is characterized in an interview by Doris González ${ }^{5}$, one of Ukamau's leaders (2021), as an organization of "self-consumption" in the sense that it summoned a small group of young people convinced of the cause who read the same books and listened to the same music, but without managing to achieve a broader mobilization of the people of the neighborhood.

Between the late "90s and early" 00s, several members of the collective began to familiarize themselves with experiences of mobilization and political work from other South American countries, such as Argentina (Frente Popular Darío Santillán), Brazil (Movimento dos Trabalhadores Sem Teto, Homeless Workers Movement) and Venezuela (Frente Nacional Exequiel Zamora), based on personal interests and concerns but also based

\footnotetext{
${ }^{5}$ Interview with Doris González, July 3, 2021.
} 
on stories of militancy of relatives linked to revolutionary and armed leftist movements. After these experiences of international exchange, the group made a self-critical reflection on the need to mobilize neighbors, to move away from an alleged vanguard position without real impact. In 2010, they made a collective diagnosis of the main problems in the Población Santiago based on questions about work, environment, education and housing. This study showed that the majority concern of the community was related to housing, which led the group to begin to study housing policies and procedures for organizing committees, plus the history of the pobladores movement. At the end of that year, the militants convened a group of women to form housing committees, the first of which was formed in 2011. From the beginning, the work on housing was aimed at politicizing the collective from the neighborhood.

The student movement of 2011 helped Ukamau politicize the community, since that episode brought back political discussion to family circles, given the direct and global impact of the commodification of education. Soon, the number of families interested in joining the committees' project grew far beyond what the movement imagined, leading them to the need for a strategic definition of how to carry out the project, eventually deciding to devise one housing complex for the 424 families that had joined the movement. With that decision in mind, they looked for a plot of land within Estación Central that could suit the size of the project. They only found two: the site of the old city gasometers (that belonged to a private company) and the land of the former workshops next to the Central Station, owned by the state-owned railroad company, which they ultimately chose. They then began a parallel process of maintaining political pressure with protests on streets and occupation of the ministry's offices, while organizing the community and conducting a surreptitious study of the property, taking photographs from neighboring buildings and even sneaking in with a surveyor to make measurements. In this process, they even approached the railroad company pretending to be representatives of a real estate company interested in buying the land for a project. Despite opposition from politicians and ministry technicians and a lack of support from the municipality, the land was finally expropriated in 2014 by the Housing and Urbanism Service (SERVIU, the public agency responsible for housing production and the only one capable of purchasing land) in order to begin the design and building process, then selling the units to the members of the organization in 2020. The innovative feature here is that Ukamau forced SERVIU to assume the role of developers, instead of relying on private companies as had been the case since 1973.

Doris González explains that a pragmatic decision was made by the movement to truly move forward: to focus on the concrete solution for families and fulfill the "dream of one's own house" rather than trying to raise a larger movement (see Figure 3). According to her, several times during the last decades the left tried to activate the struggle for housing, but ultimately diverted the energy of the movement to other ends: "we said: this is the promise that we are going to keep. And for that, we're going to use what we have today as part of our country's legal fabric, but we're going to try to go further".
Notwithstanding this pragmatist approach, González cherishes an institutional, if short-lived, achievement that opened the space for claiming the right to communities to participate in the development of their own housing. After a constant pressure on the Ministry of Housing that led to the creation of a commission and a negotiation process with the ministry and different organizations, Ukamau managed that the Ministry's Supreme Decree ${ }^{\circ} 49$-regarding a particular mechanism for housing development- included an article on self-management. González states in an interview ${ }^{5}$ that "although we knew that in practical terms there were a series of technical regulations and financial parameters that made self-management almost unfeasible, we were interested in it made known in writing so that we could claim the right."

From the point of view of commons, the Conjunto Maestranza experience has value when understood as a political and institutional management experience to learn from by other movements, rather than through the property scheme of the housing complex, which following Chilean legislation includes private ownership of housing units and a condominium model for the administration of collective spaces within the complex. Their experience is seen as a useful resource by communities from across the country, who approach them with daily requests to share their experience and collaborate with the organization of new housing committees, in line with their intention of maintaining the role of the movement rather than transforming ourselves into a housing management company, like MPL.

Although some architectural elements -like elevated walkways- were included in the project to promote community life and reinforce neighborhood identity, due to budgetary issues it was not possible to incorporate common programs or commerce within the project. However, seizing the opportunity presented by the heritage value of the Maestranza, they obtained the "transfer of use" (i.e., basically the right to use without pay) of two historic preservation properties that they destined to their housing development foundation and the headquarters of a mutual aid trade cooperative.

The Maestranza neighborhood has become an urban reference for political mobilization events, such as International Women's Day, with most of the residents still taking part in marches and protests, even children and young people (see Figure 4). Their new status as homeowners has not been a demobilization factor so far, as in other examples in Latin America (Rodríguez, 2017). For González, even if the project remains within the scheme of ownership and legal management of the current system, it challenges its rationale in terms of management models, organization and formation of political community. She highlights the role and agency of women, main promoters and leaders of the movement for the fight for habitat, who continue to be leaders in the neighborhood, both acting politically and running the administration, organizing common pots and coordinating assistance to neighbors who have suffered during the pandemic. Ukamau has also recently generated a new housing project in the form of a follow-up to the Conjunto Maestranza. It will be built in a second public railway company plot which has been expropriated by the Ministry of Housing and Urbanism to 


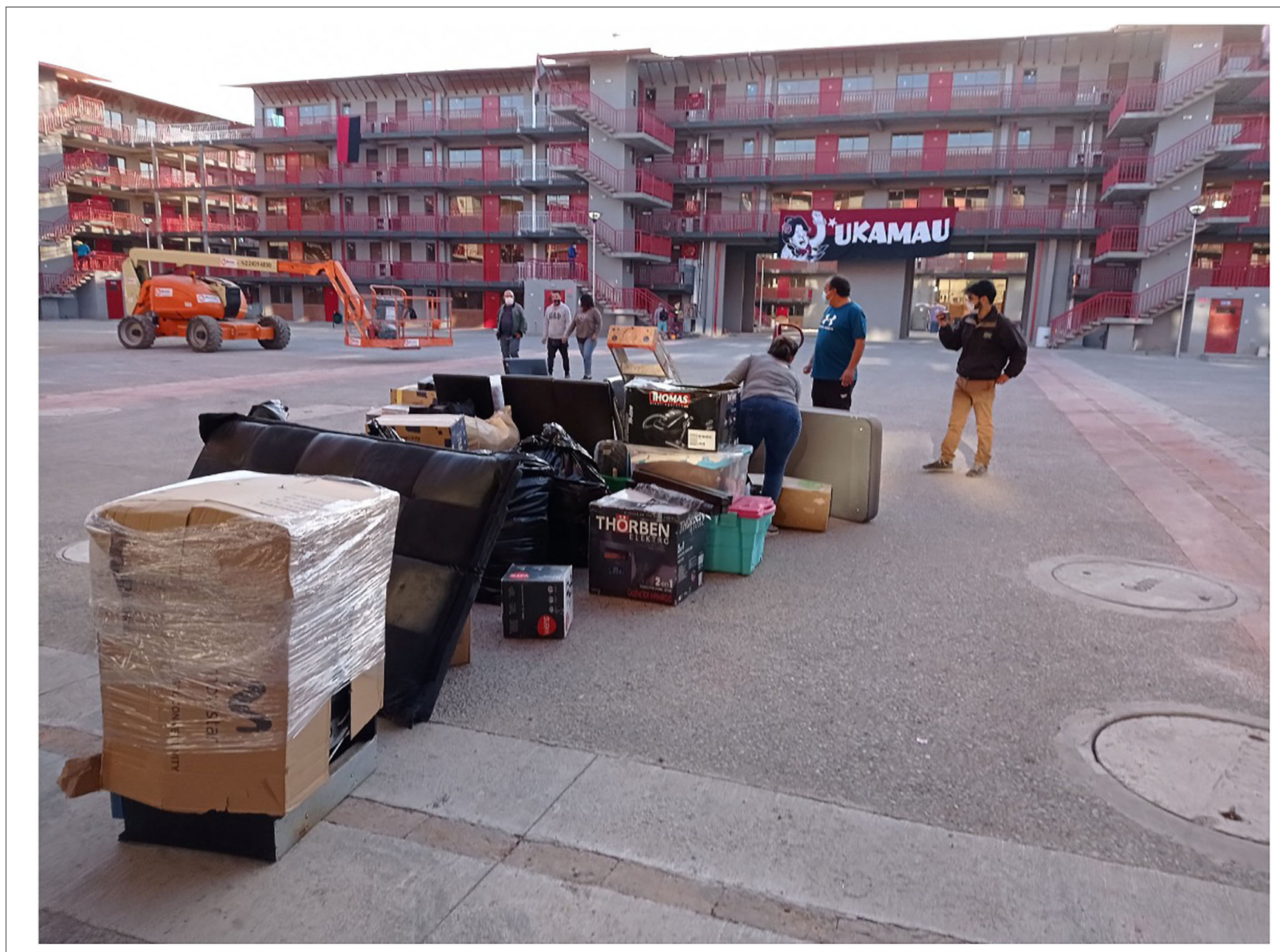

FIGURE 3 | Inauguration of Conjunto Maestranza and moving in of first residents. ๑ UKAMAU.

sell it back to the project led by Ukamau, who in turn use the housing subsidies from the same ministry to finance buying the expropriated land.

\section{LEARNINGS FROM THE COMPARISON}

While these initiatives are inspiring examples in their own right, what insights can we draw from their comparison? In this paper, we sought to connect territorialized commons and movements and explore how the use of legal strategies of appropriation mediates this relationship. Focusing on the intersections of urban housing movements and commoning experiments for collective social spaces in Berlin and Santiago de Chile, we looked at how the commoning actors relate to property law and state policies and how the legal appropriation of territories for commoning is integrated (or not) as a resource for broader movement concerns. While we don't claim the case studies of ExRotaprint and Conjunto Maestranza to be representative for any broader context, they are widely referenced and discussed in their respective national context because of their innovative approaches toward legal strategies of appropriation. While we have highlighted the novel and innovative aspects of these movements by engaging legal frameworks in creative ways, there is a continuity between these and previous movement experiences. Drawing inspiration from historical precursors, these experiments take self-initiative to produce collective spaces and housing, not waiting for the state or market to solve the issue for them.

Situated within a strikingly distinct social and political context, we cannot elucidate the differences in greater depth. However, since we consider the political links between commoning experiments and social movements, it cannot be overlooked that in the Chilean context the ownership and access to land is much more politicized than in the German case. In the case of Santiago, the right to the city and housing has fomented large mobilizations (Angelcos and Pérez, 2017; Del Romero, 2018) and it is likely to play an important role in the debates and process of the constitutional assembly, given that said right has been signaled as an important element of the idea of a "dignified life" and a new society bent on ending precarity 


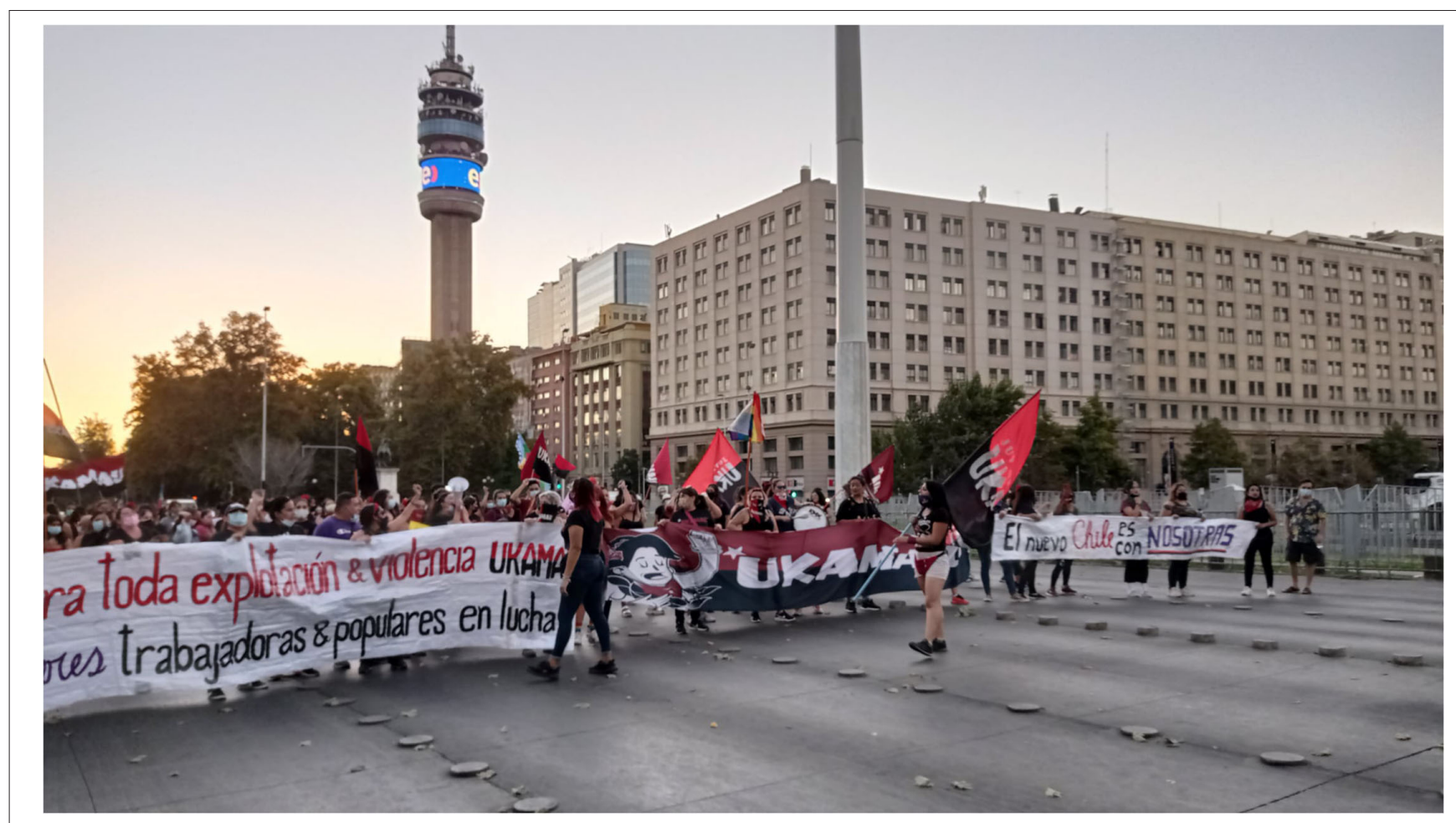

FIGURE 4 | Demonstration in downtown Santiago on Women's Day, 9 March 2021. ๑ UKAMAU.

and inequality. In Berlin, by contrast, it is only fairly recently with the controversies around rent caps and the expropriation of large private housing companies (through the initiative "Deutsche Wohnen \& Co enteignen:" https://www.dwenteignen. de) - and thus after the establishment of ExRotaprint-that an urban movement has made itself felt substantially on the political agenda. Our interviewee, Sabine Horlitz, even questioned a key assumption of our research question, namely that an urban movement exists at all. "There is a lot of talking in Berlin around urban issues, but very little gets done. It is a small set of activists that are actually involved in such projects as ExRotaprint or other." Such a statement thus places the relationship between the commons initiative and the movement context in a very different light.

Nevertheless, the commoning experiment at ExRotaprint did make a significant contribution to the urban movement in Berlin-however weak we might conceive of it. The experience of (successfully) setting up these commons initiatives has politicized several people who became involved as leaders. They have turned into well-known experts who share their experiences with other activists and engage for policies that would facilitate similar initiatives elsewhere. The use and promise of legal appropriation through Heritable Building Right in Berlin or through housing subsidy policies in Santiago (Vergara d'Alençon, 2020; Cristi, 2021) has now become known to other (potential movement) actors and travels across the national context (and beyond) mediated through manuals, presentations, etc. Significantly, both initiatives in Berlin and Santiago de Chile have contributed to politicizing the question of public land as an asset that should be put to use for civic and commons initiatives. Both cases exemplified that civic initiatives are capable of developing a larger site, a capacity that continues to be denied by experts and ruling parties for whom the quintessential developer are large private corporations.

Both initiatives have installed legal mechanisms to safeguard against the risk of commoners privatizing certain pieces and making a profit. The heritable building right at ExRotaprint prevents the initiative from selling the compound for profit. One important learning, at ExRotaprint, was that the legal instrument became an important tool to prevent the initiative from falling apart (due to profit-interests). Self-protection against speculative gains is a very common concern among commoners, especially in areas with a lot of market pressure. In her work on limited-equity cooperatives (LECs) in the USA, Huron (2015) demonstrates that this threat has led to the recommodification of many LECs into market-rate condominiums, particularly in urban environments that are sought after and thus saturated with capital investments. Several tenants, often with low-income backgrounds, thus started selling their shares capitalizing on the increase in exchange value. Reflecting on this dilemma, Amanda Huron writes, "In being caught in this tension between maintaining the collectivity of the commons and being coopted into capitalist markets, LEC members are hardly alone; commoners from the English peasantry to the native peoples of New England have succumbed to pressures of enclosure, to individualize and monetize resources previously managed in 
common. This does not make them unethical individuals, but rather points to the difficulty of maintaining commons in highly commodified landscapes" (Huron, p. 973).

At Conjunto Maestranza, members can only sell their apartments after 5 years. It remains to be seen what kind of dynamics will unfold on the site when this moratorium period has passed, though as previously mentioned, at this point the political involvement of a majority of the community and the recent news about the second stage of the project speak of a healthy commitment to the common cause and the movement. Ukamau's achievement in challenging the privatized model of housing production (Ukamau, 2020) is certainly a landmark that proves that even within the current institutional and legal framework, there are chances to innovate in terms of decommodifying housing and urban land, getting closer to a commons perspective.

Moreover, the legal frameworks also help the initiatives enshrine certain commitments to the movement and the surrounding neighborhoods. The heritable building right at ExRotaprint stipulates certain uses (i.e., one-third of the space for small businesses, one third for social services, and another third for artist studios) and also requires the initiative to preserve the built environment for future generations. In the case of Conjunto Maestranza, the condominium law regulates the use of shared spaces, such as the inner courtyards, giving every member a say to prevent individuals from appropriating territory for private benefit. The commitments of these commons spaces, however, go beyond such stipulations. Central spaces at both sites are made available for gatherings and events of movement actors. The so-called "glass box" at ExRotaprint, is available for events with rental conditions changing also whether the organizers are a profitable company or a civic organization.

Important follow-up questions for empirical research should address the social implications of engaging with legal strategies within the commoning initiatives and the movement. Given the necessity to develop expertise in engaging with the law, policies and state actors, some actors within the initiatives acquired this expertise, while others focused on other matters. In the face of such differences, what kind of social biases and conflicts do such legal strategies create within the movement? Which movement actors put these strategies to work and with what kind of implications? Our informants didn't report any major internal conflicts as a result of this differential knowledge. ExRotaprint deals with this imbalance openly within the internal structure of their initiative, distinguishing between the tenants association and the not-for-profit company that directs the operation. This operational board remains transparent to the association and the initiatives retain a commitment to participatory decision-making. However, the actual practice is not based on principles of radical democracy. While trying to remain inclusive and open for stronger participation from new members, ExRotaprint has established a certain bureaucracy and a hierarchy of decision-making powers. Moreover, the initiative welcomes the involvement of the surrounding neighborhood but there are no guarantees or rights of community participation in the project. Another aspect to consider is that the problem of a lack of collective spaces and housing is only solved for a small group of people. It doesn't resolve the problem of rising land and real estate values in the surrounding area. ExRotaprint cannot avoid gentrification and to some extent, it could be speculated that the initiatives actually contribute to gentrification by increasing the attractiveness of the neighborhood. This problem remains unsolved. In the case of Ukamau, there is an internal difference between those people who get involved in the Maestranza initiative to solve their housing need and those with a greater political commitment, who sustain the movement, have produced publications ${ }^{6}$ and from their militant position even decided in 2020 to join a political party, Comunes, which takes part in the Frente Amplio coalition and participated as movement and candidates in the elections for the constitutional assembly and the municipal and parliamentary elections, while also taking an active role in the successful presidential campaign from president-elect Gabriel Boric. Plus, the movement has been very active in promoting the discussion of the right to the city and housing within the Constitutional Convention since its installation in July 2021; actually, the first proposal of constitutional norm, made in early November by a group of ten members of the Convention from across the political map, was precisely to "ensure the right to dignified housing for all Chileans” (Alcaíno, 2021).

While both cases demonstrate innovative legal strategies for initiatives to appropriate territories, the significance of these approaches for the success of the initiative or movement dynamics should not be overstated. The primary factor is the commitment of the commoners. Engaging with the law and negotiating state bureaucracies, required acquiring expertise in both instances over years. Not knowing whether the initiative would be successful, people put a lot of effort into developing the projects, organizing the group, creating ideas, holding meetings, talking to officials etc. Legal frameworks facilitated certain processes, such as financing, regulating the use of space or preventing privatization-but they couldn't change the precarious character of these collective enterprises and the risks that commoners took upon themselves not knowing whether the initiative would successfully appropriate the territory. Legal frameworks thus supported the process of commoning appropriations but they didn't replace the activist engagements and the self-organizing of commoners and they couldn't dictate commoners' ongoing commitment to the broader movement for housing and collective spaces.

\section{DATA AVAILABILITY STATEMENT}

The raw data supporting the conclusions of this article will be made available by the authors, without undue reservation.

\footnotetext{
${ }^{6}$ Through their website, Ukamau have published several documents, such as the Manifesto for the Right to Housing and the City (https://ukamau.cl/manifiesto/), and they have also recently published a book on their history, proposals and achievements (https://ukamau.cl/2021/12/07/lanzamiento-de-nuevo-libroukamau-conquistando-la-vida-buena- una-publicacion-sobre-la-propuesta-ehistoria-de-ukamau/).
} 


\section{ETHICS STATEMENT}

Written informed consent was obtained from the individual(s) for the publication of any potentially identifiable images or data included in this article.

\section{AUTHOR CONTRIBUTIONS}

The empirical research for the Berlin case study has been conducted by DA and MK. The empirical research for the Santiago de Chile case study has been conducted by DO. The corresponding authors have written the corresponding parts. All authors contributed equally to

\section{REFERENCES}

Aernouts, N., and Ryckewaert, M. (2018). Reproducing housing commons. Government involvement and differential commoning in a housing cooperative. Housing Stud. 34, 1-19. doi: 10.1080/02673037.2018.143 2756

Agustín, Ó. G., and Jørgensen, M. B. (2019). “Autonomous solidarity: hotel city plaza," in Solidarity and the "Refugee Crisis" in Europe, eds Ó. G. Agustín and M. B. Jørgensen (Cham: Springer International Publishing), 49-72.

Alcaíno, R. (2021). La primera propuesta de la Convención Constitucional: "Derecho a una vivienda digna". Available online at: https://www.duna.cl/ noticias/2021/11/11/la-primera-propuesta-de-la-convencion-constitucionalderecho-a-una-vivienda-digna/ (accessed December 24, 2021).

Angelcos, N., and Pérez, M. (2017). De la "desaparición” a la reemergencia: continuidades y rupturas del movimiento de pobladores en Chile. Latin Am. Res. Rev. 52, 94-109. doi: 10.25222/larr.39

Barthel, B. (2020). Legal hacking und seine praktischen Dimensionen. Mietshäuser Syndikat (und HabiTAT) als Housing Commons. Juridikum 366-375. doi: 10.33196/juridikum202003036601

Bauwens, M. (2009). Class and capital in peer production. Capital Class 33, 121-141. doi: 10.1177/030981680909700107

Bernt, M., Grell, B., and Holm, A. (eds.). (2013). The Berlin Reader: A Compendium on Urban Change and Activism. Bielefeld: Transcript.

Beveridge, R., and Naumann, M. (2013). "The Berlin water company. From 'inevitable' privatization to 'impossible' remunicipalization,' in The Berlin Reader: A Compendium on Urban Change and Activism Urban Studies, eds M. Bernt, B. Grell, and A. Holm (Bielefeld: Transcript), 189-203.

Blanco, I., Salazar, Y., and Bianchi, I. (2019). Urban governance and political change under a radical left government: the case of Barcelona. J. Urban Affairs 42, 18-38. doi: 10.1080/07352166.2018.15 59648

Bollier, D., and Helfrich, S. (2019). Free, Fair, and Alive: The Insurgent Power of the Commons. Gabriola Island, BC: New Society Publishers.

Borch, C., and Kornberger, M. (2015). Urban Commons: Rethinking the City. New York, NY: Routledge.

Bunce, S. (2016). Pursuing urban commons: politics and alliances in community land trust activism in east London. Antipode 48, 134-150. doi: 10.1111 /anti.12168

Caffentzis, G. (2016). "Commons," in Keywords for Radicals: The Contested Vocabulary of Late-Capitalist Struggle, eds K. Fritsch, C. O'Connor, and A. Thompson (Oakland, CA: AK Press), 95-102.

Chiodelli, F. (2021). Why We Should Stop Publishing in Open-Access Journals With Article Processing Charges. AESOP Young Academics. Available online at: https://aesopyoungacademics.wordpress.com/2021/01/27/why-we-shouldstop-publishing-in-open-access-journals-with-article-processing-charges/ (accessed March 25, 2021).

Chua, C. (2020). Abolition is a constant struggle: five lessons from Minneapolis. Theory Event 23:S127. Available online at: https://muse.jhu.edu/article/775394 the conceptual and theoretical framework as well as to the conclusion.

\section{FUNDING}

The authors DA and MK could conduct this research through the following funding: European project OpenHeritage Organizing, Promoting, and Enabling Heritage Re-use through Inclusion, Technology, Access, Governance, and Empowerment. This project has received funding from the European Union's Horizon 2020 research and innovation programme under grant agreement No. 776766. The authors acknowledge support by the German Research Foundation (DFG) and the Open Access Publication Fund of Humboldt-Universität zu Berlin.

Connell, R. W. (2007). Southern Theory: Social Science and the Global Dynamics of Knowledge: The Global Dynamics of Knowledge in Social Science. Cambridge: Polity Press.

Cortés, A. (2014). El movimiento de pobladores chilenos y la población La Victoria: ejemplaridad, movimientos sociales y el derecho a la ciudad. EURE 40, 239-260. doi: 10.4067/S0250-71612014000100011

Cristi, I. M. (2021). Dialéctica de la liberación: la estrategia de lucha sociopolítica del MPL-Igualdad en Chile. Tabula Rasa 195-216. doi: 10.25058/20112742.n37.09

Cummings, S. L. (2021). An Equal Place: Lawyers in the Struggle for Los Angeles. Oxford: Oxford University Press.

De Angelis, M. (2017). Omnia Sunt Communia: On the Commons and the Transformation to Postcapitalism. London: Zed Books.

DeFilippis, J., Williams, O. R., Pierce, J., Martin, D. G., Kruger, R., and Esfahani, A. H. (2019). On the transformative potential of community land trusts in the United States. Antipode 51, 795-817. doi: 10.1111/anti.12509

Del Romero, L. (2018). Cartografías de la desigualdad: una década de conflictos de vivienda y nuevas resistencias en Santiago de Chile. Análisis del conflicto de la Maestranza de San Eugenio. EURE 44, 47-66. doi: 10.4067/s0250-71612018000200047

Deleuze, G. (1995). Difference and Repetition, Rev Edn. New York, NY: Columbia University Press.

Della Porta, D., Fernández, J., Kouki, H., and Mosca, L. (2017). Movement Parties Against Austerity. Cambridge: John Wiley \& Sons.

Dohnke, J. (2013). "Spree riverbanks for everyone! What remains of 'sink mediaspree'?" in The Berlin Reader. A Compendium on Urban Change and Activism, eds M. Bernt, B. Grell, and A. Holm (Berlin: Transcript), 261-274.

Edwards, B., and Kane, M. D. (2016). "Resource mobilization theory," in The Blackwell Encyclopedia of Sociology, ed G. Ritzer. doi: 10.1002/9781405165518.wbeosr060.pub2

Ersoy, C. (2015). "A place for revolution: urban space in the arab spring," in The Arab Revolution of 2011: A Comparative Perspective, ed S. A. Arjomand (Albany: SUNY Press), 113-131.

Federici, S. (2010). "Feminism and the politics of the commons," in Uses of a Whirlwind: Movement, Movements, and Contemporary Radical Currents in the United States, eds S. Hughes, S. Peace, and K. V. Meter (Oakland: AK Press), 283-294.

Friendly, A. (2017). Urban policy, social movements, and the right to the city in Brazil. Latin Am. Perspect. 44, 132-148. doi: 10.1177/0094582X16675572

Habermann, F. (2008). Der homo oeconomicus und das Andere: Hegemonie, Identität und Emanzipation. Baden-Baden: Nomos.

Hardt, M., and Negri, A. (2009). Commonwealth. Cambridge, MA: Harvard University Press.

Herrera, J. (2018). El nuevo movimiento de pobladores en Chile: el movimiento social desplazado. Polis. Rev. Latinoamericana 49, 1-19. doi: 10.4067/S0718-65682018000100177

Hettlage, R. (1987). Genossenschaftstheorie und Partizipationsdiskussion. Göttingen: Vandenhoeck \& Ruprecht. 
Holm, A., and Kuhn, A. (2011). Squatting and urban renewal: the interaction of squatter movements and strategies of urban restructuring in Berlin: squatting and urban renewal in Berlin. Int. J. Urban Regional Res. 35, 644-658. doi: $10.1111 / \mathrm{j} .1468-2427.2010 .001009 . \mathrm{x}$

Hölzl, C. (2017). The occupation of the parque indoamericano in Buenos Aires: discourse dynamics and stakeholder practices. Latin Am. Perspect. 44, 113-134. doi: $10.1177 / 0094582 X 15602661$

Huron, A. (2015). Working with strangers in saturated space: reclaiming and maintaining the urban commons. Antipode 47, 963-979. doi: $10.1111 /$ anti.12141

Imilan, W. (2016). Políticas y luchas por la vivienda en Chile: el camino neoliberal. Working Paper Contested Cities. Santiago, ISSN 2341-2755.

Initiative StadtNeuDenken and Stiftung trias (2017). Runder Tisch Liegenschaftspolitik Erbbaurechte in Berlin. Dokumentation der ExpertenWERKSTATT.

Jenkins, J. C. (1983). Resource mobilization theory and the study of social movements. Annu. Rev. Sociol. 9, 527-553. doi: 10.1146/annurev.so.09.080183.002523

Kip, M., Bieniok, M., Dellenbaugh, M., Müller, A. K., and Schwegmann, M. (2015). "Seizing the (every)day: welcome to the urban commons!", in Urban Commons: Moving Beyond State and Market, eds M. Dellenbaugh, M. Kip, M. Bieniok, A. K. Müller, and M. Schwegmann (Gütersloh; Basel: Birkhäuser), 9-25.

Kitschelt, H. P. (1986). Political opportunity structures and political protest: anti-nuclear movements in four democracies. Br. J. Polit. Sci. 16, 57-85. doi: $10.1017 /$ S000712340000380X

Kusiak, J. (2019). Legal technologies of primitive accumulation: judicial robbery and dispossession-by-restitution in Warsaw. Int. J. Urban Regional Res. 43, 649-665. doi: 10.1111/1468-2427.12827

Kusiak, J. (2021). Trespassing on the law: critical legal engineering as a strategy for action research. Area 53, 1-8. doi: 10.1111/area.12700

Kuttler, T., and Jain, A. (2015). "Defending space in a changing urban landscape a study on urban commons in Hyderabad, India," in Urban Commons: Moving Beyond State and Market, eds M. Dellenbaugh, M. Kip, M. Bieniok, A. K. Müller, and M. Schwegmann (Gütersloh; Basel: Bauverlag; Birkhäuser), 72-90.

Lehoucq, E., and Taylor, W. (2020). Conceptualizing legal mobilization: how should we understand the deployment of legal strategies? Law Social Inquiry 45, 166-193. doi: 10.1017/lsi.2019.59

Linebaugh, P. (2008). The Magna Carta Manifesto: Liberties and Commons for All. Berkeley, Los Angeles, CA; University of California Press.

Mayer, M. (1994). "Post-fordist city politics," in Post-Fordism: A Reader, ed A. Amin (London: John Wiley \& Sons, Ltd.), 316-337.

McCann, M. W. (1994). Rights at Work: Pay Equity Reform and the Politics of Legal Mobilization. Chicago, IL: University of Chicago Press.

McCarthy, J. D., and Zald, M. N. (1977). Resource mobilization and social movements: a partial theory. Am. J. Sociol. 82, 1212-1241. doi: 10.1086/226464

Mensink, S. (2020). Prefiguration, strategic interaction and political belonging in undocumented migrant and solidarity movements. J. Ethnic Migration Stud. 46, 1223-1239. doi: 10.1080/1369183X.2018.156 1251

Meyer, D. S., and Staggenborg, S. (1996). Movements, countermovements, and the structure of political opportunity. Am. J. Sociol. 101, 1628-1660. doi: $10.1086 / 230869$

Nahoum, B. (2010). Cuatro décadas de cooperativas de vivienda en Uruguay: Cambios y permanencias. Osera 3, 1-11. Available online at: https:// publicaciones.sociales.uba.ar/index.php/osera/article/view/5724

Opazo, D. O. (2015). "Creating and appropriating urban spaces - the public versus the commons: institutions, traditions, and struggles in the production of commons and public spaces in Chile," in Urban Commons: Moving Beyond State and Market, eds M. Dellenbaugh, M. Kip, M. Bieniok, A. K. Müller, and M. Schwegmann (Gütersloh; Basel: Bauverlag; Birkhäuser), 117-129.

Ostrom, E. (1990). Governing the Commons. Cambridge: Cambridge University Press.

Panelli, R., and Larner, W. (2010). Timely partnerships? Contrasting geographies of activism in New Zealand and Australia. Urban Stud. 47, 1343-1366. doi: $10.1177 / 0042098009360226$

Paulsen, A., Rodríguez, L., and Hidalgo, R. (2019). Los espacios de furia. Política y ciudad a través de las luchas urbanas por la vivienda en Santiago de Chile (19902016). Cadernos Metrópole 21, 763-782. doi: 10.1590/2236-9996.2019-4604
Peck, J., and Tickell, A. (2002). Neoliberalizing space. Antipode 34, 380-404. doi: $10.1111 / 1467-8330.00247$

Pérez, M. (2017). "A new 'poblador' is being born": housing struggles in a gentrified area of Santiago. Latin Am. Perspect. 44, 28-45. doi: $10.1177 / 0094582 X 16668318$

Pistor, K. (2019). The Code of Capital. Princeton, NJ: Princeton University Press.

Piven, F. F., and Cloward, R. (1977). Poor People's Movements: Why They Succeed, How They Fail. New York, NY: Pantheon.

Polyak, L., Patti, D., and Nasya, B. (2019). ExRotaprint | OpenHeritage. OpenHeritage. Available online at: https:/openheritage.eu/exrotaprint/ (accessed June 27, 2021).

Pruijt, H. D. (2014). "The power of the magic key. Scalability of squatting in the Netherlands and the US," in The Squatters' Movement in Europe. Commons and Autonomy as Alternatives to Capitalism, eds M. Cattaneo and M. A. Martínez (London: Pluto Press), 110-135. Available online at: https://repub.eur.nl/pub/ $113625 /$

Quijano, A., and Ennis, M. (2000). 'Coloniality of power, eurocentrism, and Latin America.' Nepantla Views South 1, 533-580. Available online at: https://www. muse.jhu.edu/article/23906

Quintana, A., and Campbell, L. M. (2019). Critical commons scholarship: a typology. Int. J. Commons 13, 1112-1127. doi: 10.5334/ijc.925

Robinson, J. (2006). Ordinary Cities: Between Globalization and Modernity. London: Routledge.

Robinson, J. (2015). Thinking cities through elsewhere: comparative tactics for a more global urban studies. Progress Human Geogr. 40, 3-29. doi: $10.1177 / 0309132515598025$

Robinson, J. (2016). Comparative urbanism: new geographies and cultures of theorizing the urban. Int. J. Urban Regional Res. 40, 187-199. doi: $10.1111 / 1468-2427.12273$

Rodríguez, A., and Sugranyes, A. (2004). El problema de la vivienda de los "con techo". EURE 30, 53-65. doi: 10.4067/S0250-71612004009100004

Rodríguez, L. (2017). Building citizenship: the struggle for housing in eastern Mexico City. Latin Am. Perspect. 44, 176-190. doi: 10.1177/0094582X16682779

Rosenberg, G. N. (1991). The Hollow Hope: Can Courts Bring About Social Change? Chicago, IL: University of Chicago Press.

Ruiz-Tagle, J., Valenzuela, F., Czischke, D., Cortés-Urra, V., Carroza, N., and Encinas, F. (2021). "Propuestas de política pública para apoyar el desarrollo de cooperativas de vivienda autogestionarias en Chile," in Propuestas para Chile. Concurso Políticas Públicas 2020, eds I. Irarrázaval, E. Piña, and I. Casielles (Santiago, CA: Centro de Políticas Públicas UC), 145-172.

Sardeshpande, M., Rupprecht, C., and Russo, A. (2021). Edible urban commons for resilient neighbourhoods in light of the pandemic. Cities 109, 1-5. doi: $10.1016 /$ j.cities.2020.103031

Schmidt, C. (1998). "The dialectics of urbanisation in Zurich," in Possible Urban Worlds, ed INURA (Basel: Birkhäuser), 216-225.

Schwarzmeier, J. (2001). Die Autonomen zwischen Subkultur und sozialer Bewegung. Weitramsdorf: J. Schwarzmeier.

Silomon-Pflug, F. (2018a). Die Verwaltung der unternehmerischen Stadt - (K)ein Thema in der geographischen Stadtforschung?! sub urban. zeitschrift für kritische stadtforschung 6, 49-68. doi: 10.36900/suburban.v6i2/3.424

Silomon-Pflug, F. (2018b). Verwaltung der unternehmerischen Stadt: zur neoliberalen Neuordnung von Liegenschaftspolitik und-verwaltung in Berlin und Frankfurt am Main. Bielefeld: Transcript. doi: 10.1515/9783839439852

Solanas, M. (2017). FUCVAM: cooperativismo de vivienda, de los barrios en Montevideo a una alternativa contrahegemónica en otros Sures. Interface J. Soc. Movements 9, 448-476. Available online at: http://www.interfacejournal. net/wordpress/wp-content/uploads/2017/07/Interface-9-1-Solanas.pdf

Stepnisky, J. (2020). Staging atmosphere on the Ukrainian Maidan. Space Culture 23, 80-97. doi: $10.1177 / 1206331218773671$

Uffer, S. (2013). “The uneven development of berlin's housing provision," in The Berlin Reader. A Compendium on Urban Change and Activism, eds M. Bernt, B. Grell, and A. Holm (Berlin: Transcript), 155-170.

Ukamau (2020). Apertura Barrio Maestranza 1 de Ukamau: Ejemplo en la democratización de la ciudad, una victoria de la organización y lucha popular. Available online at: https://ukamau.cl/2020/11/02/apertura-barriomaestranza-1-de-ukamau-ejemplo-en-la-democratizacion-de-la-ciudaduna-victoria-de-la-organizacion-y-lucha-popular/ (accessed December 24, 2021). 
Van de Geyn, B., and Draaisma, J. (2009). “The embrace of Amsterdam's creative breeding ground," in Whose Urban Renaissance, eds K. Shaw and L. Porter (London: Routledge), 202-211.

Van de Sande, M. (2017). "The prefigurative power of the common(s)," in Perspectives on Commoning: Autonomist Principles and Practices, eds G. Ruivenkamp and A. Hilton (London: Zed Books), 25-63.

Vergara d'Alençon, L. M. (2020). El rol de la sociedad civil en la gestión de vivienda y barrios vulnerables en Chile. Revista INVI 35, 62-90. doi: $10.4067 /$ S0718-83582020000300062

Vey, J. (2016). Crisis protests in Germany, Occupy Wall Street, and Mietshäuser Syndikat: Antinomies of current Marxist- and anarchistinspired movements and their convergence. Capital Class 40, 59-74. doi: $10.1177 / 0309816815627389$

Vollmer, L., and Kadi, J. (2018). Wohnungspolitik in der Krise des Neoliberalismus in Berlin und Wien. Postneoliberaler Paradigmenwechsel oder punktuelle staatliche Beruhigungspolitik? Prokla 48, 247-264. doi: 10.32387/prokla.v48i 191.83

Wendt, M. (2018). "Weil es nur zusammen geht": Commons-basierte Selbstorganisation in der Leipziger Hausprojekteszene. Frankfurt: Campus Verlag.

Wood, E. M. (2017). The Origin of Capitalism: A Longer View, New, revised and expanded edition. London; New York, NY: Verso.
Wood, L. J. (2012). Direct Action, Deliberation, and Diffusion: Collective Action After the WTO Protests in Seattle. Cambridge: Cambridge University Press.

Conflict of Interest: The authors declare that the research was conducted in the absence of any commercial or financial relationships that could be construed as a potential conflict of interest.

Publisher's Note: All claims expressed in this article are solely those of the authors and do not necessarily represent those of their affiliated organizations, or those of the publisher, the editors and the reviewers. Any product that may be evaluated in this article, or claim that may be made by its manufacturer, is not guaranteed or endorsed by the publisher.

Copyright (C) 2022 Amacher, Kip and Opazo. This is an open-access article distributed under the terms of the Creative Commons Attribution License (CC BY). The use, distribution or reproduction in other forums is permitted, provided the original author(s) and the copyright owner(s) are credited and that the original publication in this journal is cited, in accordance with accepted academic practice. No use, distribution or reproduction is permitted which does not comply with these terms. 